\title{
OS DIREITOS FUNDAMENTAIS ANALISADOS SOB A (DES)PROTEÇÃO DA HERMENÊUTICA JURÍDICA: uma revisitação ao Habeas Corpus 71.373-4/RS à luz da Teoria dos Direitos Fundamentais de Robert Alexy
}

\author{
Jorge Heleno Costa* \\ Virgínia da Costa Machado Santiago Dutra**
}

Resumo: Esse trabalho objetiva analisar a utilização da hermenêutica como técnica de interpretação de normas jurídicas, a partir de um caso julgado pelo STF (HC 71.373-4/RS), à luz da teoria dos direitos fundamentais difundida por Robert Alexy, marco teórico desta pesquisa. Tem como tema-problema investigar como é possível sentenciar um processo quando há colisão de princípios. Partindo de pesquisa bibliográfica, pelo método hipotético-dedutivo, propõe-se testar a hipótese de que talvez a solução esteja no emprego da metodologia do sopesamento e ponderação dos princípios postos em confronto.

Palavras-chave: Direitos fundamentais; Hermenêutica; Supremo Tribunal Federal; Habeas Corpus 71.373-4/RS; Robert Alexy.

\section{THE FUNDAMENTAL RIGHTS ANALYZED UNDER THE (UN) PROTECTION OF LEGAL HERMENEUTICS: \\ a revision to Habeas Corpus $71.373-4 / \mathrm{RR}$ in the light of the fundamental rights theory of Robert Alexy}

\begin{abstract}
This work aims to analyze the use of hermeneutics as a technique for interpreting legal norms, based on a case judged by the STF (HC 71.373-4/RS), in light of the theory of fundamental rights disseminated by Robert Alexy, theoretical framework of this research. It has the problem-theme to investigate how it is possible to sentence a process when there is a collision of principles. Starting from a bibliographical research, by the hypothetical-deductive method, it is proposed to test the hypothesis that perhaps the solution is in the use of the methodology of the weighing and weighting of the principles confronted.
\end{abstract}

Keywords: Fundamental rights; Hermeneutics; The Federal Supreme Court; Habeas Corpus 71.373-4/RS; Robert Alexy.

\footnotetext{
* Mestrando em Instituições Sociais, Direito e Democracia pela Universidade FUMEC. Especialista em Gestão Pública Municipal pela UFSJ. Especialista em Gestão Pública e Controle com Foco em Resultados pela Escola de Contas e Capacitação "Prof. Pedro Aleixo" - TCE/MG. Especialista em Direito Público pela PUC/MG. Especialista em Direito Municipal pela Universidade Anhanguera. Professor de Direito Constitucional no UNIPTAN. Assessor Jurídico do Município de São Tiago/MG. Advogado. Lattes: <http://lattes.cnpq.br/0877262646764607>. E-mail: jorleno23@yahoo.com.br

** Mestranda em Instituições Sociais, Direito e Democracia pela Universidade FUMEC. Especialista em Direito Processual pela UFJF. Professora de Direito Administrativo das Faculdades FEAD e Mega e do Curso Mega Concursos. Advogada. Lattes: <http://lattes.cnpq.br/1333805128835075>. E-mail: vcmsdutra@gmail.com
} 
1 INTRODUÇÃO

Todo cidadão, quando ingressa em Juízo, tem uma pretensão a ser satisfeita. Essa é uma constatação irrefutável, eis que, somente em casos específicos, pode a Justiça agir por si mesma. Como regra geral, prevalece a ideia de que os Órgãos Jurisdicionais só podem manifestar-se mediante provocação das partes.

Uma vez provocado, então, o Judiciário tem o dever de satisfazer a pretensão que lhe foi apresentada de forma eficiente, conforme prescreve a Constituição da República. Obviamente que satisfazer a pretensão das partes não significa dar-lhes o que foi pedido. Contudo, a resposta, positiva ou negativa, deve ser, efetivamente, sempre bem fundamentada, sob pena de ser invalidada, inclusive.

Ante tais premissas é que se extrai a temática de investigação deste trabalho. Dessa forma, importa saber, e essa é a problemática que orientou a presente pesquisa, como é possível sentenciar um processo quando há colisão de princípios? Como alicerce desta pesquisa, será utilizado um caso concreto, mais precisamente o Habeas Corpus 71.373-4/RS, julgado pelo Supremo Tribunal Federal.

O pressuposto problemático impõe perpassar por conceitos e questionamentos essenciais, tais como: direitos fundamentais, direito à dignidade, direito à intimidade, hermenêutica jurídica, dentre outros. Mediante a análise e convergência dos mesmos objetivase fomentar o aprofundamento teórico e prático a respeito das técnicas de interpretação, não como forma de esgotar ou elucidar a questão posta, mas sim de repensar os rumos traçados, até então, para as tomadas de decisões nos processos judiciais brasileiros, sendo que, a título de hipótese, talvez a solução esteja no emprego da metodologia do sopesamento e ponderação dos princípios postos em confronto.

Para que tal hipótese possa ser testada, a pesquisa parte dos referenciais dos direitos fundamentais, sendo que desses são destacados os já mencionados acima. Ressalta-se, também, o pensador Robert Alexy, em cuja teoria dos direitos fundamentais o presente trabalho se apoiou para fundamentar sua hipótese, bem como em juristas destacados na comunidade jurídica brasileira, como Pedro Lenza, Kildare Gonçalves Carvalho, dentre outros.

A presente pesquisa se delineou, sobretudo, pela catalogação e fichamento de fontes bibliográficas, periódicos, jurisprudências e em sítios eletrônicos. Em face da origem destes 
dados, portanto, a pesquisa se classifica, quanto ao seu delineamento, em bibliográfica e documental.

Ressalta-se a importância deste trabalho, pois, como dito alhures, não propõe uma resposta definitiva à problemática alavancada, mas, sobretudo, insta para o debate de um tema já guerreado, porém a partir da análise de um caso concreto. Nesse sentido, espera-se que tanto no âmbito da academia, bem como na prática cotidiana daqueles que vivenciam diretamente as lides forenses, tal pesquisa se apresente como proposta de se repensar as atitudes até então engendradas, a fim de que aqueles que têm por função proteger os direitos fundamentais diante dos casos concretos, em especial os julgadores, possam manejá-los de forma consciente e responsável.

Este artigo foi dividido em quatro subtítulos. No primeiro, em forma de escorço, procurou-se nortear e apresentar os direitos fundamentais de forma bem direcionada à proposta da pesquisa.

Já no segundo subtítulo, o intento foi de destacar e conceituar duas técnicas de interpretação das normas jurídicas: hermenêutica e interpretação.

O subtítulo seguinte trouxe à baila, de forma sucinta, o caso julgado pelo Supremo Tribunal Federal no Habeas Corpus 71.373-4/RS.

No quarto e último subtítulo a teoria dos direitos fundamentais de Alexy enredou o mesmo para, então, chegar-se ao âmago da discussão pretendida, conformando a citada teoria à realidade empreendida em solo brasileiro, através da análise do caso concreto apresentado.

\section{DIREITOS FUNDAMENTAIS}

A Constituição da República Federativa do Brasil, outorgada em 05 de outubro de 1988, tratou de albergar e, sobretudo, elencar os denominados direitos fundamentais. Obviamente que o rol desses direitos não se exaure na própria Constituição, eis que alguns deles vão sendo positivados ao longo do tempo, mesmo que não constando explicitamente do texto constitucional brasileiro ${ }^{1}$.

Nesse contexto, um recorte histórico se faz necessário, haja vista que Constituição da República foi instituída logo após o Estado Brasileiro ter rompido com o então vigente Regime

\footnotetext{
${ }^{1}$ Art. 5o, § 2 ${ }^{\circ}, \mathrm{CRFB} / 88:$ "Os direitos e garantias expressos nesta Constituição não excluem outros decorrentes do regime e dos princípios por ela adotados, ou dos tratados internacionais em que a República Federativa do Brasil seja parte”.
} 


\section{OS DIREITOS FUNDAMENTAIS ANALISADOS SOB A (DES)PROTEÇÃO DA HERMENÊUTICA JURÍDICA: uma revisitação ao Habeas Corpus 71.373-4/RS à luz da Teoria dos Direitos Fundamentais de Robert Alexy}

Ditatorial Militar, sob o qual padeceu vários anos. É possível questionar, portanto, se muitos dos direitos denominados "fundamentais" foram inseridos no texto da Constituição carecendo da devida estruturação jurídica, sendo que, no mesmo afã, outros tantos possivelmente podem ter sido relegados.

Assim sendo, a Constituição da República de 1988 ultimou por reunir, em um único título, os direitos e as garantias fundamentais. Nesse sentido, à guisa de distinção, imperioso trazer à baila a lição de Pedro Lenza, o qual apresenta, de forma didática, a diferenciação entre direitos e garantias fundamentais:

\footnotetext{
Assim, os direitos são bens e vantagens prescritos na norma constitucional, enquanto as garantias são os instrumentos através dos quais se assegura o exercício dos aludidos direitos (preventivamente) ou prontamente os repara, caso violados. (LENZA, 2011, p. 863).
}

Ante o rol de direitos fundamentais, portanto, é evidente que por vezes haverá conflitos entre dois ou mais desses direitos quando analisados perante um caso concreto.

A Ciência Jurídica, por sua vez, dispõe de mecanismos aptos a elidir possível conflito, sendo que, no ponto, a demonstração e o conceito de alguns desses mecanismos se fazem pertinentes.

\section{HERMENÊUTICA VERSUS INTERPRETAÇÃO}

Na seara da Ciência Jurídica tem-se que todas as decisões devem ser fundamentadas, sob pena de nulidade, conforme prescreve a Constituição da República de 1988, em seu art. 93, inciso IX. A propósito, há dez anos o Supremo Tribunal Federal refutou decisão proferida pelo Superior Tribunal Militar, a qual contou apenas com a respectiva certidão de julgamento, sem a lavratura do respectivo acórdão. Merece transcrição a ementa do Recurso Extraordinário 540995/RJ, literalmente:

RE 540995 / RJ - RIO DE JANEIRO

Relator(a): Min. MENEZES DIREITO

Julgamento: 19/02/2008 Órgão Julgador: Primeira Turma 
EMENTA: Recurso extraordinário. Garantia constitucional de fundamentação das decisões judiciais. Artigo 118, $\S 3^{\circ}$, do Regimento Interno do Superior Tribunal Militar.

1. A garantia constitucional estatuída no artigo 93, inciso IX, da Constituição Federal, segundo a qual todas as decisões judiciais devem ser fundamentadas, é exigência inerente ao Estado Democrático de Direito e, por outro, é instrumento para viabilizar o controle das decisões judiciais e assegurar o exercício do direito de defesa.

2. A decisão judicial não é um ato autoritário, um ato que nasce do arbítrio do julgador, daí a necessidade da sua apropriada fundamentação.

3. A lavratura do acórdão dá conseqüência à garantia constitucional da motivação dos julgados

4. Recurso extraordinário conhecido e provido. (BRASIL, 2008).

Considerando a decisão exarada pelo Supremo Tribunal Federal, através da ementa acima transcrita, é possível perceber de forma hialina que todas as decisões judiciais, bem como as administrativas (art. 93, X, CRFB/88), deverão conter os elementos de convicção que instruíram o julgador a proferir sua opinião ${ }^{2}$, a qual provavelmente se tornará coisa julgada por força do munus atribuído à função de quem julga e da consequência jurídica processual.

Sendo assim, para que haja uma efetiva fundamentação de qualquer decisão, o julgador deve se valer de técnicas que lhe permitam melhor abstrair os principais elementos decisórios. A hermenêutica é uma dessas técnicas, a qual é muito confundida com interpretação, mas, embora distintas, ambas se complementam, conforme se verá adiante.

\subsection{HERMENÊUTICA}

O termo hermenêutica possui raízes na seara da Ciência Filosófica, sendo que, aliás, é atribuído o surgimento da expressão ao deus grego Hermes. Nesse sentido vale elucidar que

Hermenêutica é um vocábulo derivado do grego hermeneuein, comumente tida como filosofia da interpretação. Muitos autores associam o termo a Hermes, o deus grego mensageiro, que trazia notícias. Hermes seria o deus, na mitologia grega, capaz de transformar tudo o que a mente humana não compreendesse a fim de que o significado das coisas pudesse ser alcançado. Hermes seria um "deus intérprete", na medida em que era a entidade sobrenatural dotada de capacidade de traduzir, decifrar o incompreensível. (TONELLI, 2002).

\footnotetext{
${ }^{2}$ O Código de Processo Civil, Lei n ${ }^{0}$ 13.105/2015, também exige, de forma explícita, a fundamentação nas decisões conforme previsão expressa contida no art. 489, inc. II.
} 


\title{
OS DIREITOS FUNDAMENTAIS ANALISADOS SOB A (DES)PROTEÇÃO DA HERMENÊUTICA JURÍDICA: uma revisitação ao Habeas Corpus 71.373-4/RS à luz da Teoria dos Direitos Fundamentais de Robert Alexy
}

A partir de tal compreensão, é preciso, ainda, esclarecer a correlação de Hermes com a acepção jurídica do termo hermenêutica, pois além de ser o elo entre a divindade e a humanidade, aquele deus se tornou precursor da referida expressão pelo fato de que

\begin{abstract}
Uma das qualidades mais enaltecidas de Hermes são suas relações com o mundo dos homens, um mundo por definição aberto, em permanente construção. Tem na astúcia, na inventividade, no interesse pelas atividades dos homens, na psicopompia, suas principais características, tornando-se um deus extremamente dinâmico e complexo. Hermes sabe e transmite, é inteligente e mundano, é sábio e convive com os mistérios da opacidade dos saberes diretamente inacessíveis, um perito que não contorna a complexidade, um mediador do conhecimento que resiste. Como Perséfone, que vive a metade do tempo na escuridão - como punição por haver desafiado um deus - e a outra metade na claridade do glorioso esplendor da primavera, Hermes penetra no interior das trevas e, no momento de retornar à claridade, traz consigo o conhecimento adquirido no mundo da escuridão e das opacidades. Opera por competência adquirida em mundos contrastantes e, por isso, é capaz de estabelecer nestas relações complexas conexões plurais e acomodações majorantes. (MACEDO, 1998).
\end{abstract}

A analogia à figura do deus Hermes é extremamente condizente com os propósitos da técnica hermenêutica de extração de elementos de convicção do julgador, pois ao ter contato com a divindade e, após, com a humanidade, o deus grego tem a missão de "traduzir", para esses, o que ouviu daqueles.

Notadamente, a hermenêutica jurídica vai muito além do que simplesmente traduzir frases ou expressões. Assim, a sua conceituação se apresenta necessária ante os objetivos deste trabalho:

Ciência da interpretação de textos da lei. Tem por objetivo o estudo e a sistematização dos processos a serem aplicados para fixar o sentido e o alcance das normas jurídicas e seu conhecimento adequado, adaptando-se à interpretação dos fatos sociais. (HORCAIO, 2006, p. 490-491).

Como definido, essa ciência tem como objetivo interpretar textos de lei de forma sistematizada para que determinada norma tenha seu significado aplicado ao caso concreto. Portanto, salutar discorrer acerca do termo interpretação. 


\subsection{INTERPRETAÇÃO}

No ponto, como ainda acena Tonelli (2002), o termo hermenêutica estava muito ligado, na antiguidade grega, à ideia de interpretação ou, mais precisamente, à arte da interpretação. A propósito, em relação à interpretação, Nicola Abbagnano apresenta sua teoria, aportada nas ideias do filósofo Boécio, a qual pode ser admitida sem embargos para fins dessa contextualização:

Boécio, graças a quem essa doutrina passou para a Escolástica latina, entendia por interpretação “qualquer termo que significa alguma coisa por si mesmo”, incluindo entre as interpretações os substantivos, os verbos e as preposições, e excluindo as conjunções, as preposições e em geral os termos gramaticais que não significam nada por si mesmos. Para ele, referência do signo ao que ele designa era o essencial da interpretação (In librum de interpr. editio prima, I, em P. L., 64, col. 295).

Nesta concepção, a interpretação é a referência dos signos verbais aos conceitos (as “afeições da mente”) e dos conceitos às coisas. As características dessa doutrina podem ser assim fixadas: $1^{\mathrm{a}}$ a interpretação é um evento que acontece “na alma”, um evento mental; $2^{\mathrm{a}}$ o signo verbal ou escrito é diferente da afeição da mente ou do conceito e se refere a este; $3^{\mathrm{a}}$ a relação entre signo verbal e conceito é arbitrária e convencional, ao passo que a relação entre o conceito e o objeto é universal e necessária. (ABBAGNANO, 2000, p.579).

Kildare Gonçalves Carvalho elucida que “a palavra ‘interpretação’ deriva de interpres, isto é, aquele que descobria o futuro nas entranhas das vítimas”. (CARVALHO, 2009, p. 335). O que parecia místico na antiguidade, hoje tem extrema relevância para as discussões forenses, pois analogamente ao fato de se abrir o corpo de um ser humano para descobrir o futuro, é preciso perlustrar as entranhas das normas, regras e princípios jurídicos aplicados ao caso concreto, para que o seu futuro - a decisão - seja concretizado.

Sendo assim, interpretar uma norma jurídica se revela como tarefa de alta complexidade, exigindo do intérprete jurídico astúcia e, sobretudo, comprometimento ético de forma ampla, haja vista que o conteúdo a ser interpretado produzirá efeitos práticos na vida real, no mínimo inter partes.

A despeito de tal relevância é preciso considerar que 


\title{
OS DIREITOS FUNDAMENTAIS ANALISADOS SOB A (DES)PROTEÇÃO DA \\ HERMENÊUTICA JURÍDICA: \\ uma revisitação ao Habeas Corpus 71.373-4/RS à luz da Teoria dos Direitos \\ Fundamentais de Robert Alexy
}

\begin{abstract}
A interpretação da norma jurídica consiste na atividade intelectual que tem por finalidade preeminente tornar possível a aplicação de enunciados normativos, abstratos e gerais, a situações da vida, particulares e concretas. Envolve um conjunto de métodos desenvolvidos pela doutrina e jurisprudência com base em critérios ou premissas (filosóficas, metodológicas, epistemológicas) diferentes, mas, em geral, reciprocamente, complementares. (CARVALHO, 2009, p. 336).
\end{abstract}

Ponderando as considerações esposadas, o mesmo autor arremata afirmando que “interpretar é, portanto, reconstruir o conteúdo da lei, elucidá-lo de modo a operar-se uma restituição de sentido ao texto; é a operação pela qual se atribui um sentido ao texto”. (CARVALHO, 2009, p. 336).

Como visto, embora sejam expressões distintas, hermenêutica e interpretação se interconectam na medida em que objetivam extrair a compreensão de algo, bem como, no mesmo sentido, valorar-lhe de alguma forma, com determinada finalidade. Noutras palavras, pode-se deduzir que a hermenêutica seria uma teoria que o aplicador do Direito deve perpassar para solucionar o caso concreto, ao passo que a interpretação seria a aplicação da hermenêutica, o que poderá ser verificado a partir do conhecimento do caso concreto a seguir.

\section{HABEAS CORPUS 71.373-4/RS}

Ante a proposta desta pesquisa, a pretensão resistida instaurada nos autos do Habeas Corpus 71.373-4/RS ${ }^{3}$, cuja relatoria foi do Ministro do Supremo Tribunal Federal, Francisco Resek, é, sem dúvida, paradigmática.

Em forma de escorço, trata-se o caso concreto usado para elaboração do presente trabalho de um pedido de habeas corpus preventivo impetrado pelo requerido nos autos de origem, haja vista a ordem de realização de exame pericial compulsório para fins de comprovação de paternidade, sob pena de condução coercitiva. Tal ordem emanou do Tribunal

\footnotetext{
${ }^{3}$ BRASIL. Supremo Tribunal Federal. Habeas-corpus no 71.373-4. Rel. Min. Francisco Rezek. Data Julg.: 10 nov. 1994. Disponível em: <http://www.stf.jus.br/portal/jurisprudencia/listarJurisprudencia.asp?s1=\%2871373\% 2ENUME\%2E+OU+71373\%2EACMS\%2E\%29\&base=baseAcordaos>. Acesso em: 20 jan. 2018.
} 
de Justiça do Rio Grande do Sul, após a requerente, menor, pleitear ao Judiciário que lhe fosse garantido o direito de conhecer o seu pai biológico.

Em verdade, a controvérsia dos autos teve foco, sobretudo, no direito de preservar a intimidade do suposto pai, bem como no direito à dignidade da menor em ter sua filiação reconhecida.

Como dito alhures, tal caso se tornou paradigmático no Ordenamento Jurídico Brasileiro por apresentar um embate entre princípios constitucionais de alta relevância, tanto que o julgamento acima foi acirrado, culminando pela concessão da ordem preventiva de não realização do exame pericial compulsório, por cinco votos a quatro ${ }^{4}$.

O ponto exato que levou a discussão ao Supremo foi, ainda em sede de Primeira Instância, que a Magistrada, após rever seu próprio entendimento, decidiu que

No presente caso estão em jogo interesses de duas menores. Outrossim, pelo que está
nos autos, uma das partes está faltando com a verdade e o exame dirime dúvida
estabelecendo, praticamente em definitivo, com quem está a verdade, desmascarando-
se ou a oportunista ou o que tenta eximir-se da responsabilidade da paternidade.

Não há motivo para que o réu se negue ao exame, a menos que esteja com receio do resultado. Hoje, com o avanço das pesquisas genéticas, é inconcebível que não seja feito tal exame neste tipo de ação.

Assim, determino a realização do exame, a ser realizado pelo Dr. Jobim, já compromissado. Oficie-se para marcação da data. Deverá o réu comparecer, assim que intimado, sob pena de condução sob vara, eis que, no caso, seu corpo é “objeto de direitos”, não sendo cabível invocar “direito personalíssimo do corpo”. (BRASIL, 1994).

Inconformado com tal decisão, o requerido interpôs Agravo de Instrumento, sendo que a Oitava Câmara Cível do Tribunal de Justiça do Rio Grande do Sul confirmou a sentença primeva. Posteriormente, em sede de Embargos de Declaração, mais uma vez o Tribunal Gaúcho manteve a decisão, devendo, depois de sanados os eventuais pontos omissos, ser marcado o exame pericial.

\footnotetext{
${ }^{4}$ Foram vencedores os votos dos Ministros Marco Aurélio, Moreira Alves, Néri da Silveira, Sydney Sanches e Celso de Mello e vencidos os votos dos Ministros Francisco Rezek (relator), Ilmar Galvão, Carlos Velloso e Sepúlveda Pertence.
} 


\title{
OS DIREITOS FUNDAMENTAIS ANALISADOS SOB A (DES)PROTEÇÃO DA HERMENÊUTICA JURÍDICA: uma revisitação ao Habeas Corpus 71.373-4/RS à luz da Teoria dos Direitos Fundamentais de Robert Alexy
}

Ante a frustração de tais tentativas, o requerido interpôs Recurso Especial e Recurso Extraordinário, junto ao Superior Tribunal de Justiça e Supremo Tribunal Federal, respectivamente, bem como, talvez como última alternativa, ajuizou pedido de Habeas Corpus preventivo perante a mesma Corte Suprema.

No plenário do Supremo, teses jurídicas se divergiram, ora pró, ora contra o paciente. Contudo, é preciso destacar, sobremaneira, dois votos que merecem encômios ante a riqueza doutrinária esposada.

\subsection{MINISTRO FRANCISCO RESEK}

O primeiro voto, do Ministro que relatou os autos, Francisco Resek, apresenta argumentos favoráveis à realização do exame pericial compulsório de ácido desoxirribonucléico, popularmente conhecido como DNA, nos seguintes moldes:

\begin{abstract}
Nesta trilha, vale destacar que o direito ao próprio corpo não é absoluto ou ilimitado. Por vezes a incolumidade corporal deve ceder espaço a um interesse preponderante, como no caso da vacinação, em nome da saúde pública. Na disciplina civil da família o corpo é, por vezes, objeto de direitos. Estou em que o princípio da intangibilidade do corpo humano, que protege um interesse privado, deve dar lugar ao direito à identidade, que salvaguarda, em última análise, um interesse também público. Não foi sem razão que o legislador atribuiu ao parquet, à vista da importância da determinação do vínculo de filiação, a iniciativa para que, em determinadas circunstâncias, intente a investigatória de paternidade (§ $\S 4^{\circ}$ e $5^{\circ}$ do art. $2^{\circ}$ da Lei n. 8.560/92). (BRASIL, 1994).
\end{abstract}

A par e passo desses argumentos, o então Ministro, caminhando para a conclusão do seu voto no sentido de negar a ordem, faz menção a mais um ponto guerrilhado pelo impetrante:

Um último dispositivo constitucional pertinente que o investigado diz ter sido objeto de afronta é o que tutela a intimidade, no inciso $\mathrm{X}$ do artigo $5^{\circ}$. A propósito, observou o parecer do Ministério Público: "a afirmação, ou não, do vínculo familiar não se pode opor ao direito ao próprio recato. Assim, a dita intimidade de um não pode escudá-lo à pretensão do outro de tê-lo como gerado pelo primeiro", e mais a Constituição impõe como dever da família, da sociedade e do Estado assegurar à criança o direito à dignidade, ao respeito, além de colocá-la a salvo de toda forma de negligência. Como bem ponderou o parquet federal, no desfecho de sua manifestação, "não há forma mais grave de negligência para com uma pessoa do que deixar de assumir a responsabilidade de tê-la fecundado no ventre materno...". (BRASIL, 1994). 
Baseando-se em princípios constitucionais, bem como em dispositivos da legislação infraconstitucional, portanto, o voto apresenta argumentação favorável ao pleito das requerentes, no sentido de, mesmo contra a vontade do requerido, fosse realizado o exame pericial, o qual, segundo sustenta, é o meio de prova capaz de elidir o litígio instaurado.

\title{
4.2 MINISTRO MARCO AURÉLIO
}

Tese oposta à do Ministro Francisco Resek foi apresentada pelo Ministro Marco Aurélio, sustentando que a coação impingida ao paciente para que fizesse o exame pericial seria uma afronta ao Ordenamento Jurídico como um todo. No ponto, merece transcrição parte do aludido voto:

\begin{abstract}
Ninguém está compelido, pela ordem jurídica, a adentrar a Justiça para questionar a respectiva paternidade, da mesma forma que há conseqüências para o fato de vir aquele que é apontado como pai a recusar-se ao exame que objetive o esclarecimento da situação. É certo que compete aos cidadãos em geral colaborar com o Judiciário, ao menos na busca da prevalência dos respectivos interesses e que o sacrifício - na espécie, uma simples espetadela - não é tão grande assim. Todavia, princípios constitucionais obstaculizam a solução dada à recusa. Refiro-me, em primeiro lugar, ao da legalidade, no que ninguém é obrigado a fazer ou deixar de fazer alguma coisa senão em virtude de lei. Inexiste lei reveladora de amparo à ordem judicial atacada neste habeas corpus - no sentido de o Paciente, Réu na ação de investigação de paternidade, ser conduzido ao laboratório para a colheita do material indispensável ao exame. Ainda que houvesse, estaria maculada, considerados os interesses em questão - eminentemente pessoais e a inegável carga patrimonial - pela inconstitucionalidade. Digo isto porquanto a Carta Política da República - que o Doutor Ulisses Guimarães, em perfeita síntese, apontou como a "Carta Cidadã" - consigna que são invioláveis a intimidade, a vida privada, a honra e a imagem das pessoas - inciso $\mathrm{X}$ do rol das garantias constitucionais (art. $5^{\circ}$ ). Onde ficam a intangibilidade do corpo humano, a dignidade da pessoa, uma vez agasalhada a esdrúxula forma de proporcionar a uma das partes, em demanda civil, a feitura de uma certa prova? O quadro é extravagante e em boa hora deu-se a impetração deste habeas corpus. É irrecusável o direito do Paciente de não ser conduzido, mediante coerção física, ao laboratório. É irrecusável o direito do Paciente de não permitir que se lhe retire, das próprias veias, porção de sangue, por menor que seja, para a realização do exame. A recusa do Paciente há de ser resolvida não no campo da violência física, da ofensa à dignidade humana, mas no plano instrumental, reservado ao Juízo competente - ou seja, o da investigação de paternidade - a análise cabível e a definição, sopesadas a prova coligida e a recusa do réu. Assim o é porque a hipótese não é daquelas em que o interesse público sobrepõese ao individual, como a das vacinações obrigatórias em época de epidemias, ou mesmo o da busca da preservação da vida humana, naqueles conhecidos casos em que convicções religiosas arraigadas acabam por conduzir à perda da racionalidade. (BRASIL, 1994).
\end{abstract}

Como visto, praticamente baseando-se nos mesmos pontos argumentativos destacados no outro voto, sobretudo nos princípios constitucionais, o Ministro Marco Aurélio entendeu 


\section{OS DIREITOS FUNDAMENTAIS ANALISADOS SOB A (DES)PROTEÇÃO DA HERMENÊUTICA JURÍDICA: uma revisitação ao Habeas Corpus 71.373-4/RS à luz da Teoria dos Direitos Fundamentais de Robert Alexy}

que, por bem, fosse concedida a ordem de habeas corpus a fim de que o paciente não fosse compelido à realização do exame pericial "debaixo de vara”.

Ante teses argumentativas fundamentadas praticamente nas mesmas premissas surgiram defesas opostas para um mesmo caso. Eis que paira uma indagação: como é possível chegar a um veredicto que coteje a melhor solução para determinado caso concreto?

Obviamente que no campo científico várias podem ser as vias, mas em respeito à proposta desta pesquisa, ater-se-á à teoria explanada por Robert Alexy.

\section{A TEORIA DOS DIREITOS FUNDAMENTAIS DE ROBERT ALEXY}

Nascido a 09 de setembro de 1945, em Oldenburg, na Alemanha, Robert Alexy é professor de Direito Público e de Filosofia do Direito na Universidade Christian Albrechts, em Kiel, também na Alemanha. Suas obras têm influenciado, sobremaneira, o pensamento hermenêutico-jurídico, tanto que algumas delas já foram traduzidas para vários outros idiomas.

\subsection{A TEORIA DE ALEXY}

A obra utilizada como baliza deste artigo foi publicada, originalmente, em 1985, e traz em seu bojo farta matéria doutrinária acerca do discurso jurídico, seus métodos e implicações.

Sem adentrar no mérito da obra em si, mas apenas extraindo o necessário à conformação ao caso concreto apresentado, Alexy apresenta a técnica da ponderação quando houver conflito aparente de princípios.

Entretanto, antes de se aprofundar nessa técnica, é preciso distinguir, segundo o mesmo autor, regras de princípios:

Princípios exigem que algo seja realizado na maior medida possível dentro das suas possibilidades jurídicas e fáticas existentes. Nesse sentido, eles não contêm um mandamento definitivo, mas apenas prima facie. Da relevância de um princípio em um determinado caso não decorre que o resultado seja aquilo que o princípio exige para esse caso. Princípios representam razões que podem ser afastadas por razões antagônicas. A forma pela qual deve ser determinada a relação entre razão e contrarazão não é algo determinado pelo próprio princípio. Os princípios, portanto, não 
dispõem da extensão de seu conteúdo em face dos princípios colidentes e das possibilidades fáticas.

O caso das regras é totalmente diverso. Como as regras exigem que seja feito exatamente aquilo que elas ordenam, elas têm uma determinação da extensão de seu conteúdo no âmbito das possibilidades jurídicas e fáticas. Essa determinação pode falhar diante de impossibilidades jurídicas e fáticas; mas, se isso não ocorrer, então vale definitivamente aquilo que a regra prescreve. (ALEXY, 2011, p. 103).

Partindo dessa distinção, portanto, o próprio autor assevera que os “[...] princípios são mandamentos de otimização em face das possibilidades jurídicas e fáticas”, o que parece demonstrar o grau de superioridade desses em relação às regras. No mesmo sentido, Alexy dá prosseguimento ao seu raciocínio afirmando que "a máxima da proporcionalidade em sentido estrito, ou seja, exigência de sopesamento, decorre da relativização em face das possibilidades jurídicas”. (ALEXY, 2011, p. 116).

Como visto, portanto, o zelo demonstrado nas enunciações de Alexy revela a necessidade de se analisar cada caso concreto de forma singular.

\subsection{A LEI DE COLISÃO}

Em sua teoria, Alexy prevê uma forma de solucionar os possíveis conflitos que possam surgir quando posta uma situação concreta em que princípios deverão ser analisados. Em suas palavras “quando uma norma de direito fundamental com caráter de princípio colide com um princípio antagônico, a possibilidade jurídica para a realização dessa norma depende do princípio antagônico”. (ALEXY, 2011, p. 117).

Partindo-se dos pressupostos apresentados, a solução desenvolvida pelo mesmo autor foi denominada de "lei da colisão”. (ALEXY, 2011, p. 94-99).

De forma concisa, Letícia Balsamão Amorim esclarece que

A lei de ponderação pode assim ser resumida: as condições segundo as quais um princípio precede a outro constituem o suposto de fato de uma regra que expressa a conseqüência jurídica do princípio precedente. Essa lei reflete o caráter dos princípios como mandados de otimização entre os quais, primeiro, não existem relações absolutas de precedência e que, segundo, se referem a ações e situações que não são quantificáveis. Ao mesmo tempo, constituem a base para diminuir a força às objeções 


\section{OS DIREITOS FUNDAMENTAIS ANALISADOS SOB A (DES)PROTEÇÃO DA HERMENÊUTICA JURÍDICA: uma revisitação ao Habeas Corpus 71.373-4/RS à luz da Teoria dos Direitos Fundamentais de Robert Alexy}

que resultam da proximidade da teoria dos princípios com a teoria dos valores. (AMORIM, 2005, p.127-128)

Isso significa que não há hierarquia entre os princípios, mas tão somente são os mesmos sopesados perante cada caso concreto. Entretanto, a mesma autora adverte para a observação às fases da ponderação:

\footnotetext{
Há alguns passos a serem seguidos para se fazer a ponderação. É por isso que consideramos a teoria de Alexy como procedimental: (i) primeiro se investigam e identificam os princípios (valores, direitos, interesses) em conflito, e quanto mais elementos forem trazidos mais correto poderá ser o resultado final da ponderação; (ii) segundo, atribui-se o peso ou importância que lhes corresponda, conforme as circunstâncias do caso concreto; e (iii) por fim, decide-se sobre a prevalência de um deles sobre o outro (ou outros). (AMORIM, 2005, p. 128).
}

No ponto, é presumível que a partir da observação dessas fases o resultado da ponderação seja “[...] a decisão em si, a solução corretamente argumentada conforme o critério de que, quanto maior seja o grau de prejuízo do princípio que há de retroceder, maior há de ser a importância do cumprimento do princípio que prevalece”. (AMORIM, 2005, p. 128).

\subsection{A COLISÃO DE PRINCÍPIOS NO HABEAS CORUPUS 71.373-4/RS}

No caso apresentado do Habeas Corpus 71.373-4/RS há flagrante conflito argumentativo baseado em princípios, pois de um lado estão os votos a defender o direito à dignidade das menores em ter o reconhecimento da filiação garantida e, do outro, os votos que defendem o direito do suposto pai a não ser compelido “debaixo de vara” a realizar exame pericial, sob o argumento de ver a intimidade do mesmo preservada.

A ementa do acórdão em liça apresenta os argumentos que deram provimento à ordem pleiteada, nos exatos termos:

INVESTIGAÇÃO DE PATERNIDADE - EXAME DNA - CONDUÇÃO DO RÉU "DEBAIXO DE VARA". Discrepa, a mais não poder, de garantias constitucionais implícitas e explícitas - preservação da dignidade humana, da intimidade, da intangibilidade do corpo humano, do império da lei e da inexecução específica e direta 
de obrigação de fazer - provimento judicial que, em ação civil de investigação de paternidade, implique determinação no sentido de o réu ser conduzido ao laboratório, "debaixo de vara", para coleta do material indispensável à feitura do exame DNA. A recusa resolve-se no plano jurídico-instrumental, consideradas a dogmática, a doutrina e a jurisprudência, no que voltadas ao deslinde das questões ligadas à prova dos fatos. (BRASIL, 1994).

Assim, para aqueles que de supetão restringem a leitura apenas à ementa do acórdão, redundam por talvez acreditar que a questão era por demasiada simplória, sendo que, na verdade, não é. O próprio Ministro Marco Aurélio advertiu: “Senhor Presidente, quando o nobre Relator começou a relatar este habeas corpus, a matéria pareceu-me de simplicidade franciscana, mas vejo que não é, e que os enfoques - e já temos dois votos no sentido da denegação da ordem - são diversos”. (BRASIL, 1994).

Corroborando com essas considerações, o Ministro Sepúlveda Pertence também se dirigiu ao Presidente do Supremo à época, afirmando que “[...] o brilho dos votos que me antecederam mostra que o caso retrata um confronto de valores constitucionais relevantes”. (BRASIL, 1994).

Notório, portanto, que os princípios contrapostos nesse caso exigiram dos Ministros uma profícua hermenêutica, justamente porque se tratava de uma decisão complexa a ser proferida, pois de ambos os lados estavam partes albergadas por princípios constitucionais tidos como fundamentais.

Com o intento de esquadrinhar uma possível solução para o impasse, vale retomar a o pensamento de Letícia Balsamão Amorim, para quem

As colisões de princípios devem ser solucionadas de maneira totalmente distinta. Quando dois princípios estão em colisão, um dos dois princípios tem que ceder ante o outro. Mas isso não significa declarar inválido o princípio desprezado nem que no princípio desprezado haja que ser introduzida uma cláusula de exceção. O que vai determinar qual o princípio que deve ceder serão as circunstâncias. Isso quer dizer que, nos casos concretos, os princípios têm diferentes pesos e que prevalece o princípio com maior peso.

Enquanto o conflito de regras se resolve na dimensão da validade, a colisão de princípios - considerando que só podem colidir princípios válidos - tem lugar mais além da validade, resolve-se na dimensão do peso. (AMORIM, 2005, p.127). 


\section{OS DIREITOS FUNDAMENTAIS ANALISADOS SOB A (DES)PROTEÇÃO DA HERMENÊUTICA JURÍDICA: uma revisitação ao Habeas Corpus 71.373-4/RS à luz da Teoria dos Direitos Fundamentais de Robert Alexy}

Novamente, a leitura desatenta do texto pode conduzir a conclusões equivocadas. De certo que o peso é um fator que deve ser considerado quando da apreciação da situação concreta, mas no caso em apreço essa é uma tarefa árdua. As palavras proferidas no voto do Ministro Carlos Velloso não deixam dúvida a esse respeito:

Daí resultar para o filho, ao que penso, o direito de conhecer o seu pai biológico. Esse direito se insere naquilo que a Constituição assegura à criança e ao adolescente: o direito à dignidade pessoal.

Esse interesse não fica apenas no mero interesse patrimonial. A conseqüência da não submissão do ora impetrante ao exame, apontou o Senhor Ministro Marco Aurélio, seria emprestar a essa resistência o caráter de confissão ficta. Isso, entretanto, se tem importância para a satisfação de meros interesses patrimoniais, não resolve, não é bastante e suficiente quando estamos diante de interesses morais, como o direito à dignidade que a Constituição assegura à criança e ao adolescente, certo que essa mesma Constituição assegura aos filhos, havidos ou não da relação do casamento, ou por adoção, os mesmos direitos e qualificações, proibidas quaisquer designações discriminatórias relativas à filiação. Também desse dispositivo constitucional $-\S 6^{\circ}$ do artigo 227 - defluem interesses morais que vão além dos interesses patrimoniais. Ora, Senhor Presidente, não há no mundo interesse moral maior do que este: o do filho conhecer ou saber quem é o seu pai biológico. (BRASIL, 1994).

A eloquência dos termos desse voto instiga a dúvida quanto ao deslinde do julgamento em análise, sendo que após serem apresentados tantos argumentos válidos a favor da denegação da ordem, como seria possível a ordem ter sido concedida?

Muito embora não seja pretensão desse artigo manifestar-se a respeito do mérito do julgamento, mas tão somente demonstrar a possibilidade de se ponderar acerca dos direitos fundamentais, aplicados num caso concreto, à luz da teoria alexiana, é preciso considerar que os argumentos em favor das requerentes são factíveis, ou seja, podem ser admitidos. Entretanto, no mesmo patamar encontram-se os argumentos em favor do requerido, suposto pai, sendo que os direitos que defende foram conquistados pelo Ordenamento Jurídico Brasileiro de forma árdua.

Efetivamente é preciso considerar que a ordem jurídica estabelecida não pode ser rompida sob o argumento de se garantir outros direitos. Explica-se: os direitos defendidos pelo paciente do habeas corpus foram se consolidando paulatinamente, ao ponto de se solidificarem com a promulgação da Constituição da República de 1988. Deveras que, por si só, este argumento não invalida os direitos das requerentes, sobretudo por serem menores e pleitearem dignidade e respeito. 
Contudo, o fator decisivo, no caso apresentado, é meramente processual. Haja vista a magnitude de todos os princípios apresentados prevaleceu o argumento de que em se tratando de reconhecimento de paternidade, é possível fazer outros tipos de prova, à exceção do exame pericial, principalmente na modalidade coercitiva. Interpretando-se a análise dos Ministros, portanto, se fosse admitida tal possibilidade, a decisão poderia ser considerada como um retrocesso jurídico.

\subsection{PERSPECTIVAS DA (DES)PROTEÇÃO HERMENÊUTICA}

O horizonte jurídico brasileiro, tanto do ponto de vista jurisprudencial, quanto doutrinário, ainda vislumbra e contempla timidamente a aurora da hermenêutica, entendida assim se for considerada a comparação entre os juristas brasileiros e o próprio Alexy, bem como outros autores, também de nacionalidade alemã, como Jürgen Habermas, por exemplo. Em verdade, existem consideráveis trabalhos a respeito do tema em solo nacional ${ }^{5}$.

Entretanto, a disseminação das técnicas de hermenêutica e de argumentação jurídica parece que deve ser uma constante no Ordenamento Jurídico Brasileiro, sobretudo levando-se em consideração a advertência da Professora Cláudia Toledo, quando da apresentação à edição brasileira da Teoria da Argumentação Jurídica, também de autoria de Robert Alexy:

Embora alguns critiquem a utilidade do estudo de uma teoria da argumentação jurídica em países periféricos, que ainda caminham para tornar-se “verdadeiros” Estados Democráticos de Direito em virtude especialmente de suas desigualdades sociais, é pela observância de critérios e objetivação de metas que podem tais Estados se pautar para a consecução dos ideais de institucionalização da democracia, em seus procedimentos argumentativos em qualquer instância, desde a intersubjetiva particular quanto a pública, realizada nos Poderes Legislativo, Executivo e Judiciário. A busca de um interesse comum (ou majoritário) de correção nas ações judiciais, normas, instituições etc. caracteriza, fundamenta a validade das regras do discurso no

\footnotetext{
${ }^{5}$ A respeito dos temas hermenêutica e interpretação jurídica, cf.: GRAU, Eros Roberto. Ensaio e discurso sobre a interpretação/aplicação do direito. São Paulo: Malheiros, 2002; GALUPPO, Marcelo Campos. Os princípios jurídicos no estado democrático de direito: ensaio sobre o modo de sua aplicação. Revista de Informação Legislativa, Brasília, ano 36, n. 143, jul./set. 1999; BARACHO JUNIOR, José Alfredo de Oliveira. A nova hermenêutica na jurisprudência do Supremo Tribunal Federal. In: SAMPAIO, José Adércio Leite (Coord.). Crise e desafios da Constituição. Belo Horizonte: Del Rey, 2004; dentre outros.
} 


\section{OS DIREITOS FUNDAMENTAIS ANALISADOS SOB A (DES)PROTEÇÃO DA HERMENÊUTICA JURÍDICA:}

uma revisitação ao Habeas Corpus 71.373-4/RS à luz da Teoria dos Direitos Fundamentais de Robert Alexy

estabelecimento de um Estado em que se tente fazer prevalecer o Direito. Ao mesmo tempo, é cumprindo-se sempre mais as regras da argumentação jurídica que mais se possibilitam as chances de consensos fundados que democraticamente consolidam o Estado. (ALEXY, 2011, p. 1).

Nesse sentido, tem-se que, ao menos no campo da presunção, que a hermenêutica deve passar por processos de aprimoramento, sobretudo a partir da concepção holística epistemológica, isto é, conhecendo-se profundamente as técnicas ao ponto de serem utilizadas na interpretação jurídica como um todo.

Afinal, aqueles que procuram se albergar do pálio da Justiça não esperam outra resposta a não ser aquela que seja efetivamente justa, eis que ninguém se submete a ser parte processual a não ser com o objetivo de proteger seus direitos. Todos os cientistas jurídicos, principalmente os intérpretes, sabem que esse é o ápice da Ciência Jurídica.

E, partindo desses pressupostos, o corolário de todo e qualquer processo judicial, que é a sentença ou o acórdão, necessita de argumentos válidos e devidamente interpretados, a fim de que os direitos levados a juízo sejam efetivados à luz das normas contidas na Constituição da República, sob pena de se ver todo o arcabouço jurídico ruir ante uma decisão não fundamentada a partir das premissas hermenêuticas.

\section{CONCLUSÃO}

O presente artigo, mesmo que sumariamente, envidou esforços no sentido de reavivar a discussão, a partir da análise de um caso concreto, acerca de um dos temas ainda controvertidos no Ordenamento Jurídico Brasileiro contemporâneo: a hermenêutica jurídica.

Como visto, esta é uma discussão que ainda se apresenta de forma acanhada no cenário forense. Porém, ao intérprete da Ciência Jurídica, sobretudo no âmbito da academia, é dever repensar os rumos das técnicas de interpretação das normas, como um todo, pois, afinal, todos os brasileiros são detentores de direitos fundamentais, estando sujeitos a confrontos em nível de princípios, inclusive. 
Foi com esse espírito, portanto, que o presente trabalho procurou acalorar, ainda mais, a discussão sobre o tema da hermenêutica, porém a partir da análise de um caso concreto à luz da teoria dos direitos fundamentais de Robert Alexy.

Assim, partindo dos pressupostos constitucionais de confirmação dos direitos fundamentais é que se tem a efetiva compreensão da relevância dos mesmos no campo da dignidade e da cidadania. O ser humano é, enquanto cidadão, sujeito de direitos e garantias fundamentais, por isso a necessidade de distingui-los nesse trabalho.

Foi visto que o termo hermenêutica advém da analogia à mitologia grega, mais precisamente ao deus Hermes, tendo, modernamente, adquirido status de técnica de interpretação de normas jurídicas. Entretanto, a própria interpretação também se reveste de caracteres de técnica autônoma, devendo ambas se conformar para melhor alcançar os propósitos dos julgados.

O paradigmático caso do Habeas Corpus 71.373-4/RS, julgado pelo Supremo Tribunal Federal, foi utilizado como premissa para fins desta pesquisa, sendo a repercussão dos fatos que levaram a demanda até a Corte Suprema, bem como o posicionamento dos Ministros avençado nos votos, é que serviram de análise científica.

Assim, conformando o caso concreto à luz da teoria dos direitos fundamentais de Alexy foi possível perceber que quando houver colisão de princípios jurídicos, no caso, especificamente, constitucionais, cabe aos julgadores fazerem juízo de sopesamento para se saber, afinal, qual deles deverá prevalecer. Por óbvio que essa não é a única solução aplicável, mas de acordo com Alexy, a valoração é crucial para que determinado princípio seja utilizado como argumento a ser considerado, já que não existe preponderância entre princípios.

Tais premissas teoréticas, analisadas sobre o prisma do caso concreto descrito alhures, possibilitaram, portanto, confirmar a hipótese inicialmente aventada, ou seja, talvez a solução para elidir o confronto de princípios esteja no emprego da metodologia do sopesamento e ponderação dos mesmos.

\section{REFERÊNCIAS}

ABBAGNANO, Nicola. Dicionário de filosofia. 4. ed. São Paulo: Martins Fontes, 2000. 


\section{OS DIREITOS FUNDAMENTAIS ANALISADOS SOB A (DES)PROTEÇÃO DA HERMENÊUTICA JURÍDICA:}

uma revisitação ao Habeas Corpus 71.373-4/RS à luz da Teoria dos Direitos Fundamentais de Robert Alexy

ALEXY, Robert. Teoria da argumentação jurídica: a teoria do discurso racional como teoria da fundamentação jurídica. Tradução de Zilda Hutchinson Schild Silva. Revisão técnica da tradução e introdução à edição brasileira de Claudia Toledo. 3. ed. Rio de Janeiro: Forense, 2011.

ALEXY, Robert. Teoria dos direitos fundamentais. Tradução de Virgílio Afonso da Silva. 2. ed. São Paulo: Malheiros, 2011.

AMORIM, Letícia Balsamão. A distinção entre regras e princípios segundo Robert Alexy: esboço e críticas. Revista de Informação Legislativa. Brasília a. 42 n. 165 jan./mar. 2005.

BRASIL, Planalto. Constituição da República Federativa do Brasil de 1988. Disponível em: <http://www.planalto.gov.br/ccivil_03/constituicao/constitui\%C3\% A7ao.htm>. Acesso em 20 jan. 2018.

BRASIL. Supremo Tribunal Federal. Habeas Corpus 71.373-4/RS. Rel. Min. Francisco Rezek. Data Julg.: 10 nov. 1994. Disponível em: <http://www.stf.jus.br/portal/jurisprudencia/listarJurisprudencia.asp?s1=\%2871373\%2ENUM E\%2E+OU+71373\%2EACMS\%2E\%29\&base=baseAcordao>. Acesso em: 20 jan. 2018.

BRASIL. Supremo Tribunal Federal. Recurso Extraordinário 540995. Rel. Min. Menezes Direito. Data Julg.: 19 fev. 2008. Disponível em: $<\underline{\text { http://www.stf.jus.br/portal/jurisprudencia/listarJurisprudencia.asp?s1=\% }}$ 28540995\%2ENUME\%2E+OU+540995\%2EACMS\%2E\%29\&base=baseAcordaos >. Acesso em: 20 jan. 2018.

BULOS, Uadi Lammêgo. Curso de direito constitucional. 4. ed. São Paulo: Saraiva, 2009.

CARVALHO, Kildare Gonçalves. Direito constitucional. 15. ed. rev. atual. e ampl. Belo Horizonte: Del Rey, 2009. 
DUARTE, Bernardo Augusto Ferreira. Em busca da legitimidade dos discursos jurisdicionais relativos ao direito à saúde: uma análise a partir da reviravolta hermenêuticolinguístico-pragmática. 2011. 520 f. Dissertação (Mestrado em Direito) - Pontifícia Universidade Católica de Minas Gerais, Belo Horizonte.

HORDONES, Fabrício Vargas. O “jeitinho” brasileiro como juízo aristotélico de eqüidade. 2007. 96 f. Dissertação (Mestrado em Direito) - Pontifícia Universidade Católica de Minas Gerais, Belo Horizonte.

LENZA, Pedro. Direito constitucional esquematizado. 15. ed. rev. atual. e ampl. São Paulo: Saraiva, 2011.

LIMA CASTRO, Dayse Starling (coord.). Direito público. Belo Horizonte: PUC Minas, Instituto de Educação Continuada, 2010.

MACEDO, Roberto Sidnei. Hermes re conhecido. Etnopesquisa-crítica, currículo e formação docente. In: Simpósio “Etnografia e Prática Escolar”, UFRN, junho/1998, Natal. Disponível em: $<$ http://www.revistafaced.ufba.br/include/getdoc.php?id= 789\&article $=231 \&$ mode $=$ pdf $>$. Acesso em: 22 jan. 2018.

MARINONI, Luiz Guilherme. O direito à tutela jurisdicional efetiva na perspectiva da teoria dos direitos fundamentais. Disponível em: < $\underline{\text { http://www.egov.ufsc.br/ }}$ portal/sites/default/files/anexos/15441-15442-1-PB.pdf>. Acesso em: 17 jan. 2018.

MORAES, Alexandre de. Direito constitucional. 12. ed. São Paulo: Atlas, 2002.

NERY JUNIOR, Nelson; NERY, Rosa Maria de Andrade. Constituição Federal comentada e legislação constitucional. 2 ed. rev., ampl. e atual. São Paulo: Revista dos Tribunais, 2009.

NETA, Vellêda Bivar Soares Dias. A interpretação dos direitos fundamentais: argumentação jurídica e hermenêutica na motivação das decisões judiciais. In: ENCONTRO NACIONAL DO CONPEDI, XIX, 2010, Fortaleza. Disponível em: 


\section{OS DIREITOS FUNDAMENTAIS ANALISADOS SOB A (DES)PROTEÇÃO DA HERMENÊUTICA JURÍDICA:}

uma revisitação ao Habeas Corpus 71.373-4/RS à luz da Teoria dos Direitos Fundamentais de Robert Alexy <http://www.conpedi.org.br/manaus/arquivos/anais/fortaleza/3698.pdf $>$. Acesso em: 20 jan. 2018.

PEDRON, Flávio Quinaud. Comentários sobre as interpretações de Alexy e Dworkin. Revista CEJ. v. 9 n. 30 jul./set. 2005. Disponível em: <http://www2.cjf.jus.br/ojs2/ index.php/cej/article/view/680/860>. Acesso em: 15 jan. 2018.

PINHEIRO, Guilherme César. Teoria da argumentação e jurisprudência dos valores: a fundamentação das decisões em oposição à ideia de discricionariedade judicial. Revista de Direito Público. Londrina, v. 5, n. 3, p. 133-149, dez. 2010. Disponível em: <http://www.uel.br/revistas/uel/index.php/direitopub/article/view/7555>. Acesso em: 28 jan. 2018.

SANTOS, Roseli Rêgo. Direito à identidade pessoal e genética: suas implicações na inseminação artificial heteróloga. Disponível em: <http://www.egov.ufsc.br/portal/ sites/default/files/anexos/33551-43458-1-PB.pdf>. Acesso em 18 jan. 2018.

SCHONBLUM, Paulo Maximilian Wilhelm. Exame de DNA: faculdade ou obrigatoriedade? Indício, presunção ou prova? Disponível em: <http://www. cgvadvogados.com.br/html/downloads/Exame_de_DNA-Faculdade_ou_ Obrigatoriedade_Indicio_Presuncao_ou_Prova.pdf>. Acesso em: 20 jan. 2018.

SIDNEI MACEDO, Roberto. Hermes re conhecido. Etnopesquisa-crítica, currículo e formação docente. In: Simpósio “Etnografia e Prática Escolar”, UFRN, junho de 1998. Natal. Disponível em: $\quad<\underline{\text { http://www.revistafaced.ufba.br/include/getdoc.php?id= }}$ 789\&article=231\&mode=pdf $>$. Acesso em: 20 fev. 2018.

STREK, Lenio Luiz. Hermenêutica, neoconstitucionalismo e o "problema da discricionariedade dos juízes”. Disponível em: <http://www.anima-opet.com.br/ primeira_edicao/artigo_Lenio_Luiz_Streck_hermeneutica.pdf>. Acesso em: 20 fev. 2018. 
TAVARES, André Ramos. Constituição do Brasil integrada com a legislação e a jurisprudência do STF. 2. ed. rev., ampl. e atual. São Paulo: Saraiva, 2007.

TONELLI, Maria Luiza Quaresma. Hermenêutica jurídica. e-Gov - UFSC, Santa Catariana, 2002. Disponível em: <http://www.egov.ufsc.br/portal/conteudo/hermen\% C3\%AAuticajur\%C3\%ADdica>. Acesso em: 20 fev. 2018.

TORRES, Ricardo Lobo. O direito ao mínimo existencial. Rio de Janeiro: Renovar, 2009. 